\title{
Analisis Faktor-Faktor Penyebab Rendahnya Daya Serap Siswa pada Pelajaran Akuntansi
}

\author{
Elisa Haryani ${ }^{1}$, Syarwani Ahmad ${ }^{1}$, Riswan Aradea $^{1}$ \\ ${ }^{1}$ Universitas PGRI Palembang
}

$\triangle$ Corresponding author

(elisaharyaniharyani05@gmail.com)

\begin{abstract}
Abstrak
Tujuan dalam penelitian ini adalah untuk mengetahui faktor-faktor penyebab rendahnya daya serap siswa kelas XI di SMK Negeri 2 Prabumulih dengan menganalisis hasil dari penyebaran angket kepada siswa kelas XI di SMK Negeri 2 Prabumulih. Teknik dalam penelitian ini adalah kuantitatif. Berdasarkan hasil penelitian ini diketahui bahwa daya serap siswa dipengaruhi oleh faktor sekolah dengan jumlah 8 pernyataan yaitu kemampuan guru dalam menguasai materi, kemampuan guru di dalam pengelolaan kelas, metode mengajar guru yang disenangi siswa, kondisi gedung sekolah dan ruang kelas, relasi siswa, guru yang bersahabat, alat belajar dan pembelajaran, penyediaan media belajar yang mencukupi sebesar 58,5\% dengan kategori kurang, faktor psikologis sebesar 36,9\% termasuk kategori sangat kurang dengan jumlah 5 pertanyaan yaitu minat belajar siswa, daya ingat siswa, IQ siswa, motivasi, dan persiapan dalam proses belajar, faktor fisik sebesar 30,55\% termasuk kategori sangat kurang dengan jumlah 4 pertanyaan yaitu kesehatan jasmani, kesehatan mata, kesehatan telinga, dan keoptimalan dalam belajar, dan faktor keluarga sebesar 22,5\% termasuk kategori sangat kurang dengan jumlah 4 pertanyaan yaitu pemilihan waktu belajar, pemanfaatan waktu yang baik dalam belajar, dan lingkungan belajar yang nyaman dan kondusif.
\end{abstract}

Kata Kunci: Faktor-faktor; Penyebab rendahnya daya serap siswa; Pelajaran Akuntansi.

\begin{abstract}
The purpose of this study was to determine the factors causing the low absorption of class XI students at SMK Negeri 2 Prabumulih by analyzing the results of the distribution of questionnaires to class XI students at SMK Negeri 2 Prabumulih. The technique in this research is quantitative. Based on the results of the study, it is known that student absorption is influenced by school factors with a total of 8 statements, the teacher's ability to master the material, the teacher's ability in classroom management, teacher teaching methods that please students, school and classroom conditions, student relations, close teachers, tools learning and learning, the provision of adequate learning media is $58.5 \%$ in the less category, psychological factors of $36.9 \%$ are in the very poor category with 5 questions, namely student learning interest, student memory, student IQ, motivation, and preparation in the learning process, physical factors $30.55 \%$ included in the very poor category with a total of 4 questions, namely physical health, eye health, ear health, and family factors of $22.5 \%$ including the very poor category with a total of 4 questions, namely the selection of study time, time utilization good in learning, and a comfortable and conducive learning environment.
\end{abstract}

Keywords: Factors, Causing the Low Absorption, Accounting Lessons

\section{PENDAHULUAN}

Pendidikan adalah suatu usaha dalam rangka menyiapkan siswa melalui bimbingan, pengajaran dan latihan untuk dapat memainkan perannya dalam lingkungan hidup dan 
sekitarnya. Pendidikan juga basis utama yang berkontribusi ke semua sektor dengan menyediakan yang diperlukan yaitu keterampilan maupun ilmu pengetahuan proses pembelajaran agar peserta didik memahami tentang sesuatu yang diajarkan dan membuat mereka menjadi manusia yang mampu berpikir kritis dalam menyelesaikan tugas pembelajaran. Pembelajaran yang baik harus diperlukan dukungan dari berbagai pihak yang terlibat dalam proses belajar mengajar untuk meningkatkan pembelajaran yang berkualitas. Pihak-pihak tersebut adalah peserta didik, guru dan orang tua. Peserta didik merupakan pihak yang utama karena peserta didik merupakan pihak yang sedang belajar dan memerlukan pemahaman terhadap guru,selain pihak peserta didik dan guru pihak orang tua juga sangat penting guna untuk mendukung proses belajar mengajar sebagai motivasi serta dukungan bagi peserta didik agar anaknya menjadi lebih semangat dan termotivasi dalam menjalankan proses belajar mengajar.

Dalam meningkatkan keberhasilan belajar siswa disekolah tentunya harus ada upaya yang dilakukan, salah satu usaha yang dilakukan ialah tentunya dengan mengetahui tolak ukur daya serap siswa dalam memahami materi pelajaran yang disampaikan. Daya serap merupakan suatu tolak ukur seorang pendidik untuk mengetahui sejauh mana kemampuan seorang peserta didik dalam menguasai dan memahami suatu materi pembelajaran yang di ajarkan atau disampaikan dalam proses belajar mengajar. Dalam proses belajar mengajar biasanya sering terganggu karena rendahnya daya serap siswa dalam memahami materi pelajaran yang di ajarkan. Daya serap sangat berpengaruh dalam proses pembelajaran karena apabila daya serap seorang peserta didik rendah akan menyulitkan dalam mengikuti proses belajar mengajar dan akan mempengaruhi prestasi dan hasil belajar seorang peserta didik tersebut. Daya serap sangat berpengaruh dalam proses belajar, dengan begitu hal ini sangat perlu di perhatikan guna untuk meningkatkan hasil dan prestasi belajar peserta didik. Dari penjelasan di atas masih banyak sekali Siswa Sekolah Menengah Kejuruan (SMK) yang belum terlalu menguasai pelajaran akuntansi dan masih rendahnya daya serap mereka terhadap pelajaran dan pemahaman tentang akuntansi karena kita ketahui siswa SMK harus bisa lebih menguasai pelajaran akuntansi untuk mencapai standar kompetensi dan dapat menjadikan bekal bagi mereka untuk memudahkan mereka memasuki dunia kerja.

Analisis adalah proses mencari dan menyusun secara sistematis data yang diperoleh dari hasil wawancara, catatan lapangan, dan dokumentasi, dengan cara mengorganisasikan data ke dalam kategori, menjabarakan kedalam unit-unit, melakukan sintesa, menyusun kedalam pola, memilih mana yang penting dan yang akan dipelajari, dan membuat simpulan sehingga mudah dipahami oleh diri sendiri maupun orang (Hardani, 2020).

Di dalam suatu proses belajar mengajar, tingkat pemahaman seorang siswa sangatlah penting terhadap materi pembelajaran yang disampaikan oleh guru guna untuk mencapai keberhasilan proses belajar mengajar. Apabila siswa tidak mampu memahami atau sulit memahami materi yang disampaikan oleh guru maka proses belajar mengajar akan sedikiti terhambat. Maka dari itu daya serap siswa sangatlah berperan penting dalam proses belaja mengajar guna untuk tercapainya tujuan pembelajaran yang baik.

Daya serap adalah kemampuan atau kekuatan untuk melakukan sesuatu untuk bertindak dalam menyerap pelajaran. Daya serap berasal dari kata "daya" yang berarti kekuatan, kemampuan dan "serap" yang berarti mengambil. Jadi daya serap dapat dikatakan sebagai suatu kemampuan untuk menungkap dan memahami sebuah materi ynag diterima dengan benar. Dan daya serpa menjadi tolak ukur untuk mengetahui sejauh mana pemahaman peserta didik terhadap pelajaran yang diajarkan oleh seorang guru dalam proses kegiatan belajar mengajar (Prasetyo, 2018).

Daya serap merupakan salah satu faktor yang dapat mempengaruhi usaha yang dilakukan seseorang. Daya serap yang kuat atau tinggi akan menimbulkan usaha yang mudah dalam menghadapi masalah atau problem khususnya dalam bidang pendidikan. Jika seorang siswa memiliki daya serap yang tinggi terhadap mata pelajaran yang di sampaikan oleh guru maka dengan cepat ia dapat mengerti, menyerap dan memahami pelajaran tersebut (Najahah, 
2015). Abdul Wahid menulis tentang fungsinya daya serap bagi anak 1) daya serap dapat meningkatkan wawasan dan pola pikir anak. Sebagai contoh anak yang mempunyai daya serap tinggi pada mata pelajaran, maka wawasan tentang pelajaran luas, serta dapat berpikir luas tentang manfaat ilmu yang diserap pada waktu pelajaran; 2) daya serap sebagai tenaga pendorong yang kuat, daya serap anak untuk menguasai pelajaran bisa mendorongnya untuk terus belajar dan ingin lebih tau secara mendalam; 3) prestasi selalu dipengaruhi daya serap yang tinggi, untuk dapat mengerjakan soal tes dengan baik dan benar, tentunya diharapkan siswa mempunyai daya serap yang tinggi terhadap mata pelajaran; 4) daya serap dapat meningkatkan minat belajar. Minat seseorang berbeda-beda meskipun diajar oleh guru yang sama dan diberi pelajaran tapi antara satu anak dan yang lain mendapatkan jumlah pengetahuan yang berbeda. Hal ini terjadi karena berbedanya daya serap mereka dan daya serap ini dipengaruhi oleh intensitas minat mereka. Untuk memahami, menyerap atau menguasai materi yang dipelajarinya sesuai dengan bahan mata pelajaran yang diajarkan gurunya dalam proses kegiatan belajar mengajar. Untuk meningkatkan kualitas belajar sisiwa.

Menurut Arnike (2013) yang dijadikan sebagai tolok ukur dalam menyatakan suatu proses belajar mengajar dapat dikatakan berhasil adalah apabila daya serap terhadap mata pelajaran yang diajarkan mencapai prestasi tinggi. Dari pernyataan tersebut, dapat disimpulkan bahwa pada hakikatnya daya serap belajar erat kaitannya dengan prestasi belajar, karena semakin baik daya serap siswa dalam belajar maka siswa akan mendapatkan prestasi belajar yang semakin baik juga, sehingga faktor yang mempengaruhinya sama dengan faktor yang mempengaruhi prestasi belajar (Dimyati, 2012).

Faktor yang mempengaruhi prestasi belajar dapat digolongkan menjadi dua, yaitu faktor internal dan faktor eksternal. Faktor internal adalah faktor yang berasal dari dalam individu yang sedang belajar, sedangkan faktor eksternal adalah faktor yang ada diluar individu (Slameto 2015). Faktor internal, meliputi faktor jasmani, terdiri atas faktor kesehatan dan cacat tubuh. Faktor psikologis, terdiri atas intelegensi, perhatian, motivasi, minat, bakat, motif, kemandirian, kematangan, kelelahan. Faktor eksternal, meliputi faktor keluarga terdiri atas cara orang tua mendidik, relasi antar anggota keluarga, suasana rumah, keadaan ekonomi keluarga, perhatian orang tua, latar belakang kebudayaan keluarga. Faktor sekolah terdiri atas metode mengajar, kurikulum, relasi guru dan siswa, relasi siswa dengan siswa, disiplin sekolah, alat pelajaran, waktu sekolah, standar pelajaran, keadaan gedung, metode mengajar, dan tugas rumah. Faktor masyarakat terdiri atas kegiatan seseorang dalam masyarakat, media massa, teman bergaul, dan bentuk kehidupan masyarakat yang heterogen.

Beradasarkan faktor-faktor yang telah disebutkan diatas, peneliti hanya akan menjadikan faktor internal yaitu faktor fisik dan faktor psikologis dan faktor eksternal yaitu faktor sekolah dan faktor keluarga sebagai variabel faktor yang mempengaruhi daya serap siswa. Faktor internal, faktor fisik seperti gangguan indrawi, hal ini bisa kita ketahui dengan kurangnya fungsi pendengaran, penglihatan, pembau, perasa dan peraba (Slameto, 2015). IQ, kurangnya IQ yang dimiliki peserta didik juga berdampak terhadap rendahnya daya serap, hal ini dikarebakan IQ anak tersebut tidak bisa menyerap pelajaran dengan baik (Karyotomo, 2019). Daya ingat merupakan fungsi otak yang terdiri dari menerima, memasikan, menyimpan dan mengeluarkan kembali informasi yang diperoleh oleh siswa dan mengingat sendiri itu dapat didefinisikan sebagai pengetahuan sekarang tentang masa lampau (Karyotomo, 2019). Kesehatan mental merupakan konsep ideal, artinya kesehatan mental menjadi tujuan yang amat tinggi bagi seseorang. Disarankan orang agar mendapatkan kondisi sehat yang paling optimal untuk berusaha terus mencapai kondisi sehat setinggi-tingginya (Sochib, 2018). Kurang optimal dalam penggunaan fungsi otak, hal ini biasanya dikarenakan tidak terbiasa dengan budaya membaca, sehingga otak lambat dalam menganalisa, biasanya kebiasaan dalam belajar cuma menghafal (Slameto, 2015). Faktor psikologis, minat adalah kecenderungan yang tetap untuk memperhatikan dan mengenang beberapa kegiatan. Kegiatan yang diminati seseorang, diperhatikan terus menerus yang disertai dengan rasa senang (Slameto, 2015). Minat merupakan kecenderungan yang menetap untuk memperhatikan dan mengenang beberapa 
aktivitas, minat yang kuat akan menimbulkan usaha untuk mencapai tujuannya. Minat juga disebut suatu rasa lebih suka dan rasa ketertarikan pada suatu hal aktivitas, tanpa ada yang menyuruh (Sardiman, 2012). Motivasi merupakan kata yang berasal dari kata "motif" yang artinya sebagai daya upaya yang mendorong seseorang untuk melakukan sesuatu. Menurut Sadirman (2012) motivasi adalah perubahan energi dalam diri seseorang yang ditandai dengan munculnya "feling" dan didahului dengan tanggapan terhadap adanya tujuan.

Dengan adanya motivasi dapat mendorong siswa untuk lebih bersemangat dalam mengikuti proses belajar mengajar. Motivasi dapat juga dilakukan dengan cara pemberian hadiah agar proses belajar mengajar dapat dilakukan lebih bergairah walaupun sifatnya sementara. Dari sini dapat dilihat bahwa motivasi dapat menentukan keberhasilan suatu proses pembelajaran, siswa yang memiliki motivasi belajar tinggi akan cenderung lebih tinggi prestasinya begitupun sebaliknya apabila motivasi belajarnya rendah maka akan rendah pula tingkat prestasinya. Bakat merupakan suatu kemampuan individu yang kelihatan menonjol jika dibandingkan dengan kemampuan-kemampuannya yang lain. Misalnya, Denok terlihat sangat jelas kemampuannya yang sangat baik dalam bidang hitung menghitung atau matematika, Tomy lebih menonjol kemampuannya di bidang menggambar (Prasetyo, 2018).

Faktor eksternal, faktor keluarga antara lain kesiapan menurut Jamies Drever adalah Preparedness to respond or react. Kesiapan adalah kesediaan untuk memberi response atau bereaksi. Kesediaan itu timbul dari dalam diri seseorang dan juga berhubungan dengan kematangan, kesiapan ini perlu diperhatikan dalam proses belajar, karena jika siswa belajar dan padanya sudah ada kesiapan, maka hasil belajarnya akan lebih baik (Slameto, 2015).

Lingkungan yang nyaman atau kondusif Dalam arti yang luas lingkungan mencakup iklim dan geografis, tempat tinggal, adat istiadat, pengetahuan, pendidikan dan alam. Suasana pembelajaran dapat menyenangkan bagi siswa jika guru dapat menghadirkan dan memanfaatkan humor dengan tepat. Apabila pembelajaran yang nyaman dan kondusif maka materi yang disampaikan guru dapat diterima dengan mudah oleh siswa dan siswa akan lebih tertarik dalam materi yang disampaikan oleh guru (Aris, 2015). Faktor sekolah, guru yang bersahabat dengan peserta didik, bersikap akrab atau bersahabat dengan siswa sebaiknya dilakukan dalam suasana santai dan bersifat dari hati ke hati sehingga siswa tidak merasa kaku dan sungkan dalam berhubungan dengan guru. Guru juga harus mengembangkan sikap kesederajatan agar bisa diterima sebagai teman atau mitra kerja oleh siswa (Djamarah, 2008).

Relasi guru dengan siswa, sebuah hubungan interpersonal yang bersifat timbal-balik dan menyatu. Hubungan ini berperan untuk mengatur prilaku siswa dalam kelompok social yang kecil. Aris (2015) menyatakan bahwa relasi guru-siswa dibentuk dari interaksi dan kerja sama (Djamarah, 2008). Alat dan media pembelajaran, dalam pembelajaran tertentu yang memerlukan alat dan media, belajar tidak akan mencapai hasil yang maksimal jika tanpa alat dan media tersebut (Lestari, 2018). Kondisi gedung tempat belajar dan kondisi sekolah yang baik, kondisi gedung terutama ditunjukan pada ruang kelas atau ruang tempat proses belajar mengajar. Adapun ruang kelas harus memenuhi syarat kesehatan seperti : ruang kelas harus mempunyai jendela, ventilasi yang cukup, udara segar dan matahari dapat masuk ruangan, dinding harus bersih tidak kotor, keadaab gedung harus jauh dari keramaian seperti (pasar, bengkel, pabrik, dll), sehingga siswa berkonsentrasi. Apabila beberapa hal diatas tidak terpenuhi maka daya serap akan terganggu dan menyebabkan terhambatnya proses belajar mengajar (Slameto, 2015).

Metode mengajar, suatu alat dalam pelaksanaan pendidikan, yakni yang digunakan dalam penyampaian materi tersebut, materi yang mudah pun kadang sulit berkembang dan sulit diterima oleh peserta didik, karena cara atau metode yang yang digunakannya kurang tepat. Namun, sebaliknya suatu pelajaran yang sulit akan mudah diterima oleh peserta didik, karena penyampaian dan metode yang digunakan mudah dipahami, tepat dan menarik (Sardiman, 2012).

Menurut (Wasty, 2006) hasil pengukuran memiliki fungsi utama untuk memperbaiki tingkat penguasaan peserta didik. Adapun langkah-langkah untuk meningkatkan daya serap 
siswa 1) memperjelas tujuan intruksional, pendidik melaksanakan tugasnya sesuai dengan persiapan yang telah direncanakan. Ia menyampaikan kepada peserta didik tujuan intruksional yang ingin dicapai melalui pelajaran. Jadi peserta didik pada awal pembelajaran sudah mengetahui arah dan tujuan yang ingin dikuasainya, dan diharapkan dalm pembelajaran peserta didik dan pendidik berupaya untuk mencapai tujuan tersebut, dan ini akan membawa kedua belah pihak secara bersama-sama ingin berhasil mencapai apa yang direncanakan. Keberhasilan ini dapat diketahui setelah dilaksankan pengukuran; 2) Penilaian awal yang menentukan kebutuhan peserta didik, penilaian awal ini diperoleh dengan mempelajari catatan kemajuan dari sekolah asal, sebelum peserta didik mengikuti program yang dikembangkan, dan melalui tes awal (pre-test) yang dikembangkan untuk mengetahui tingkat pengusaan peserta didik tentang materi yang akan diberikan. Tes awal dapat digunakan sebagai pelengkap atas catatan kemajuan yang diterima dari sekolah, atau satu-satunya sumber yang tepat digunakan untuk merancang program yang sesuai dengan kemampuan peserta didik. 3) Memonitor kemajuan peserta didik, monitoring kemajuan peserta didik selama proses pembelajaran bertujuan untuk mengarahkan peserta didik pada jalur yang membawa hasil-hasil belajar yang maksimal. Monitoring dilkasnakan secara berkeseninambungan dan terus menerus. Pertanyaan lisan atau tulisan yang diberikan pada waktu proses belajar mengajar merupakan kegiatan untuk mengetahui kemajuan atau pemahaman peserta didik. Pertanyaan-pertanyaan ini dapat disajikan untuk perorangan (individual) atau kelompok.

\section{METODE PENELITIAN}

Dalam kamus besar Bahasa Indonesia, objek adalah hal, perkara, atau orang yang menjadi pokok pembicaraan. Dengan kata lain objek penelitian adalah sesuatu yang menjadi fokus dari sebuah penelitian. Jika kita bicara tentang objek penelitian, objek inilah yang akan dikupas dan dianalisis oleh peneliti berdasarkan teori-teoriyang sesuai dengan objek penelitian. Objek dalam penelitian ini merupakan "Faktor-Faktor Penyebab Rendahnya Daya Serap Siswa". Sedangkan, Informan (narasumber) adalah seseorang yang memiliki informan mengenai objek penelitian tersebut (Syofian, 2010). Informan dalam Penelitian ini adalah "Siswa Kelas XI Akuntansi SMK N 2 Prabumulih berjumlah 34 Siswa". Metode penelitian merupakan proses kegiatan dalam bentuk pengumpulan data, analisis dan memberikan interpretasi yang terkait dengan tujuan penelitian (Sugiyono 2017). Dalam penelitian ini peneliti menggunakan metode deskriptif yang dimana metode deskriptif merupakan bentuk analisis data penelitian untuk menguji generalisasi hasil penelitian berdasarkan satu sampel. Hasil analisisnya dilakukan dengan pengujian hipotesis deskriptif. Dalam penelitian ini peneliti menggunakan siswa SMK N 2 Prabumulih.

Fokus dalam penelitian ini dimaksudkan untuk membatasi studi kualitatif sekaligus membatasi penelitian guna membeli mana data yang relevan dan mana yang tidak relevan (Arikunto, 2010). Penelitian ini akan difokuskan kepada " Faktor Penyebab Rendahnya Daya Serap" Sub fokus dalam penelitian ini yaitu "Siswa Kelas XI". Teknik pengumpulan data merupakan langkah yang paling utama dalam penelitian, karena tujuan utama dari penelitian adalah mendapatkan data. Tanpa mengetahui teknik pengumpulan data, maka peneliti tidak akan mendapatkan data yang memenuhi standar data yang ditetapkan (Sugiyono, 2017). Teknik yang digunakan dalam pengumpulan data pada penelitian adalah dengan menggunakan angket (kuesioner) yang dilakukan dengan cara memberi seperangkat pertanyaan atau pernyataan tertulis kepada responden untuk dijawabnya. Kuesioner merupakan teknik pengumpulan data yang efisien bila peneliti tahu dengan pasti variabel yang akan di ukur dan tahu apa yang bisa diharapkan dari responden (Sugiyono, 2017). Teknik analisis data faktorfaktor penyebab rendahnya daya serap. Dalam menganalisis data faktor-faktor penyebab rendahnya daya serap siswa pada pembelajaran akuntansi peneliti menggunakan perhitungan dengan menggunakan rumus persentase sebagai berikut: 


\section{$\mathrm{P} \frac{f}{N} \times 100 \%$}

Keterangan :

$P$ : Persentase sub variabel

$f$ : Nilai yang diperoleh

$\mathrm{N}$ :Jumlah siswa angket

\section{HASIL DAN PEMBAHASAN}

Tabel 1. Rekapitulasi Keseluruhan Hasil Angket Siswa

\begin{tabular}{ccccccccc}
\hline No & Aspek & SS & S & N & TS & STS & Total & Rata-rata \\
\hline 1 & Faktor Keluarga & 130 & 116 & 24 & 0 & 0 & 450 & $22,5 \%$ \\
2 & Faktor Sekolah & 650 & 380 & 124 & 16 & 0 & 1.170 & $58,5 \%$ \\
3 & Faktor Fisik & 425 & 136 & 48 & 2 & 0 & 611 & $30,5 \%$ \\
4 & Faktor & 405 & 240 & 92 & 2 & 0 & 739 & $36,9 \%$ \\
& $\begin{array}{l}\text { Psikologis } \\
\quad \sum\end{array}$ & 1.385 & 872 & 288 & 20 & 0 & 660 & \\
& Rata-rata & $69,3 \%$ & $43,6 \%$ & $14,4 \%$ & $1,0 \%$ & $0 \%$ & & \\
& & & & & &
\end{tabular}

Dari tabel 1 dapat dijelaskan kesimpulan bahwa rendahnya daya serap siswa dapat dilihat dari Faktor Keluarga 22,5\%, Faktor Sekolah 58,5\%, Faktor Fisik 30,5\%, Faktor Psikologis $36,9 \%$. Jadi dari hasil di atas dapat dikategorikan yang tertinggi dari faktor penyebab rendahnya daya serap siswa pada pembelajaran akuntansi yaitu Faktor Sekolah sebesar 58,6\% dan faktor terendah dari faktor penyebab rendahnya daya serap siswa pada pembelajaran akuntansi yaitu Faktor Keluarga sebesar 22,5\%. Dengan demikian bahwa daya serap siswa kelas XI di SMK Negeri 2 Prabumulih dipengaruhi oleh keempat faktor diatas yakni faktor keluarga, faktor fisik, faktor psikologis dan faktor sekolah karena dilihat dari hasil penyebaran angket setelah di analisis keempat faktor tersebut termasuk kedalam kategori sangat kurang (Ahmad, 2016).

\section{KESIMPULAN}

Berdasarkan hasil analisis data dan pembahasan, diketahui bahwa rendahnya daya serap siswa pada pelajaran Akuntansi kelas XI di SMK Negeri 2 Prabumulih Tahun Ajaran 2020/2021 dipengaruhi oleh faktor sekolah dengan jumlah 8 pertanyaan yaitu kemampuan guru dalam menguasai materi, kemampuan guru di dalam pengelolaan kelas, metode mengajar guru yang disenangi siswa, kondisi gedung sekolah dan ruang kelas, relasi siswa, guru yang bersahabat, alat belajar dan pembelajaran, penyediaan media belajar yang mencukupi sebesar 58,5\% dengan kategori kurang, faktor psikologis sebesar 36,9\% termasuk kategori sangat kurang dengan jumlah 5 pertanyaan yaitu minat belajar siswa, daya ingat siswa, IQ siswa, motivasi, dan persiapan dalam proses belajar, faktor fisik sebesar 30,55\% termasuk kategori sangat kurang dengan jumlah 4 pertanyaan yaitu kesehatan jasmani, kesehatan mata, kesehatan telinga, dan keoptimalan dalam belajar, dan faktor keluarga sebesar 22,5\% termasuk kategori sangat kurang dengan jumlah 4 pertanyaan yaitu pemilihan waktu belajar, pemanfaatan waktu yang baik dalam belajar, dan lingkungan belajar yang nyaman dan kondusif. Jadi, faktor penyebab rendahnya daya serap siswa ialah disebabkan oleh keempat faktor yaitu faktor keluarga, faktor sekolah, faktor fisik, dan faktor psikologis.

\section{DAFTAR PUSTAKA}

Ahmad, F. (2016). Daya Serap Terhadap Pembelajaran Taksonomi. Jurnal Pustaka, 52. Aris, K. (2015). Pengertian Analisis Menurut Para Ahli. Jurnal. 
Arnike, A. M. (2013). Kecerdasan Emosi Mahasiswa . Jurnal Emba, 903.

Dimyati. (2012). Belajar dan Pembelajaran . Jakarta: PT. Asdi Mahasa.

Djamarah. (2008). Psikologi Belajar. Jakarta: PT. Rineka Cipta.

Hardani. (2020). Metode Penelitian Kuantitatif dan Kualitatif. Jakarta: CV. Pustaka IImu Group.

Karyatomo. (2019). Buku Ajar Dasar-Dasar Akuntansi. Yogyakarta: Deepublish.

Najahah. (2015). Potensi Daya Serap Anak Didik Terhadap Pelajaran . Jurnal Lentera, 163,167.

Lestari, N. D . (2018). Analisis Penggunaan Sarana dan Prasarana untuk Menunjang Kegiatan Belajar Mahasiswa di Universitas PGRI Palembang Tahun 2016/2017. Jurnal Manajemen, Kepemimpinan dan Supervisi Pendidikan, 46.

Prasetyo, N. F. (2018). Faktor-Faktor yang Mempengaruhi Daya Serap Siswa Pada Mata Pelajaran Ekonomi Kelas XI IIS SMA Sentolo. Jurnal Daya Serap Siswa,13

Sardiman. (2012). Interaksi Motivasi dan Belajar Mengajar . Jakarta: PT. Raja Grafindo Raja. Slameto. (2015). Belajar dan Faktor-Faktor yang Mempengaruhinya. Jakarta: Rineka Cipta.

Sochib. (2018). Buku Ajar Pengantar Akuntansi. Yogyakarta: Deepublish.

Sugiyono. (2017). Statiska Untuk Penelitian . Bandung: Alfabeta.

Arikunto, S. (2010). Prosedur Penelitian. Jakarta: Rineka Cipta.

Syofian, S. (2010). Statiska Deskriptif Untuk Penelitian . Jakarta: PT. Raja Grafindo Persada.

Wasty, S. (2006). Psikologi Pendidikan. Jakarta: PT. Rineka Cipta. 